\section{MANAGERIAL TECHNICAL WRITING}

David Ayers: Currie, Coopers \& Lybrand, Vancouver, B.C.

\section{INTRODUCTION}

Recently our firm of management consultants was asked to assist in the recruitment of a Technical Writer for one of our major clients.

We placed an advertisement that went something like this:

\section{TECHNICAL WRITER}

Vancouver Head office

Our clfent is XYZ Mining Ltd., now managing the start-up of the largest underground copper mine in Canada.

You will report directly to the Vice-President of Copper Operations and consult with other vice-presidents and project managers on the preparation of a varlety of reports and presentations. These reports will be received by corporate head office, government agencies, shareholders and customers.

Your most important qualification is an abllity to quickly produce clear and well-organized written explanations of complex engineering and commerctal data. Other desirable qualifications include a university degree, a background in the engineering or commercial disciplines and experience in working effectively with senior executives.

At present the position is for an eighteen-month term, which may later be extended. Salary and benefits are substantial, reflecting the importance of the work.

Send your resume and a one-page sample of your technical writing to David Ayers of Currie, Coopers Lybrand....

Not long after this advertisement appeared in the local newspaper I was paid a visit by your TECHNOSTYLE Editor, Joan Pavelich. She suggested that the advertisement represented one of the top positions to which a technical writer could aspire and that a description of our selection process could be valuable information for teachers of technical writing. Joan was particularly interested in getting a business person's point-of-view.

As we talked I recalled my own personal transition from the academic world into business some three years ago. The most difficult part of that transition was learning to abandon an academic style of technical writing in favour of a business style.

\section{OVERVIEW}

I hope to pass along two kinds of Information in this article. The first concerns the technical writer position that we advertised. In particular, I will:

- Describe the position

- Give an overview of the selection process

- Discuss the qualifications and experience of candidates who were good prospects to fill the position.

It happened that the key ingredient for candidate success was the possession of a certain style of technical writing that we can call "managerial technical writing." 
The second kind of Information I hope to share is a description

of managerial technical writing and how this differs from:

- Academic writing, and

- Other kinds of technical writing.

\section{BACKGROUND TO THE TECHNICAL WRITER POSITION}

$X Y Z$ Mining Ltd. was in the construction phase of mine development for one of the largest new mines in North America. Construction and start-up are demanding periods for the management of any new mine since production must begin on time and within budget in order to profitably meet contract comitments. Only a year ago $X Y Z$ had been a small exploration and development division of a larger company. At that time feasibility studies on the mining property had been completed and contract negotiations were underway with potential purchasers of copper.

\section{Once contracts were signed, $X Y Z$ began its rapid transformation} from a small development of 1 ce to a very large operating mine. The amount of coordination, organization and detalled decisionmaking that is required by such a process might be compared to the staffing, construction and opening of a large new university - from scratch. As always in a mine start-up, the new top management team found itself stretched very thin. Each vice-president and manager was making scores of decistons dally, and nearly every decision had profit-and-loss implications. Twelve-hour day, sixday weeks were common.
It was against this background that the Technical Writer position was advertised. Managers and vice-presidents were not finding the time to write needed reports. In fact, they weren't even finding the time to review the applications for Technical Writer. It took just over a month for $X Y Z$ executives to $f$ ind the two hours needed to review a set of screened resumes. This situation is fairly common. It only indicates that a decision regarding a technical writer was not as critical as other decisions, and the delay gives us a flavour of the time pressures faced by senior management during a start-up.

\section{THE REAL POSITION DESCRIPTION}

The background for the position has been described at length in order to provide a flavour of the work environment and the demands that will be placed on the successful candidate. It we set aside any formal position description and look at the job as it really will be, the person who is hired will:

- Consult with (1.e. try to catch) a number of vicepresidents and managers to assist them in writing major reports on a variety of technical and financial topics.

- Produce a great deal of polished written material,

- In a short time

- for a variety of different people simultaneously

- with little supervision

- and no training

- and most importantly, with less than complete Information at the start of each task. 
I wish I could tell you that a technical writing position at this sentor level would be much less demanding in a different industry setting. The fact is, however, that industry typically demands high productivity from every position - but Industry also pays highly skilled and productive people very well. I expect that the starting salary for this position will be at least $\$ 32,000$ per year, and if significant technical expertise is needed it could pay $\$ 45,000$ per year or more.

\section{THE SELECTION PROCESS}

We required each applicant to submit a sample of their technical writing along with a resume. These were carefully screened according to criteria that I will outline later. Then, since XYZ was not sure about the level of expertise that they wanted, we presented some sample resumes at each of three levels of estimated present salary. The $\$ 25,000-\$ 35,000$ group included many of the professional technical writer applicants as well as some junior engineers and geologists with excellent writing skills. The $\$ 35,000-\$ 55,000$ group was composed mostly of intermediate-level professional engineers in mining-related disciplines, some of whom also had MBA's or other degrees demonstrating breadth of interest. Every one in this group had held supervisory, project management or consulting positions that would require the authorship of sentor-level technical reports. The $\$ 55,000$ and up group was composed entirely of people who had held senior management positions. In all cases an excellent technical writing sample was required.
We will then soon be interviewing approximately eight people. We will then check six employment-related references for each promising candidate. These references will include as many previous supervisors as possible. Our experience has been that thorough reference checking provides the best information on a candidate's potential performance, and past supervisors generally provide very candid information.

We w1ll then present three candidates to $\mathrm{XYZ}$, and these candidates will be interviewed by at least two XYZ managers before a hiring decision is reached.

In the intervlews we will be looking for people who are well-spoken, conceptually well organized and verbally facile. Anything less will mean that the person will take too long to produce what is needed in the way of writing, even though their final product might be excellent. We will also be looking for technical depth, ease of relating with senior management and familiarity with corporate reporting requirements and styles.

\section{WHO WAS LONG LISTED?}

Each application was carefully screened according to a simple energy saving criterion: "Can this person do the job?"

For the purpose of writing this article I then went back again and took a systematic look at all of the applications to see if there was a pattern to my,judgements that I could articulate. With great relief I discovered that there was indeed. This exercise was valuable because it led to the Identification of something that 
we can call "managerial technical writing." The balance of this article will shortly focus on managerial technical writing, but first let's look at the kinds of things that had little effect on whether a candidate made the long list. These were as follows:

- The number of years of experience had little ef fect, except in the case of very junior people. Those with five years' experience or less were not of ten long listed, but the ratio of applicants to long listed candidates remained constant for all other applicants regardless of the number of years of experience.

- The nature of a candidate's degree or diploma had 11ttle effect. The ratio of applicants to long listed candidates remained essentially the same whether their degree was in arts, education, science, engineering or business. While the nature of a degree or diploma had little effect, possessing a formal qualification had a substantial effect. It happened that no applicant was long listed who falled to possess a degree or diploma, and this is probably because such candidates simply did not have the background needed to produce a good technical writing sample.

- A candidate's experience in previous positions was also not a critical variable, but let me qualify this. I mean that it made little difference whether the applicant had been a professional technical writer, an engineer or a manager. What will 11kely make a difference in the $f$ inal selection is previous experience in the mining industry.

\section{MANAGERIAL TECHNICAL WRITING - THE KEY INGREDIENT}

The critical ingredient that led to long listing was the demonstrated ability to produce managerial-level technical writing. We can define this first by way of contrast to other kinds of technical writing.

The writing samples submitted by applicants appeared to sort themselves into four broad categories. These categories can be defined as follows :

- Popularized technical writing introduces a lay person to a technical subject. Its function is to educate and of ten to entertain.

- Instructive technical writing provides clear and of ten step-by-step information that will allow the reader to do a technical task or perform a technical function.

- Scientific technical writing is essentially technical communication from scientist to scientist with no attempt to simplify the technical material.

- Managerial technical writing succinctly summarizes all of the important detalls of a technical or financial situation so that a manager may make a judgement or reach a decision.

Without exception, any applicant who submitted a sample of clear, polished and technically sound managertal technical writing was long 1isted. 
In addition, there were a few candidates long listed who did not submit such a sample. These people by and large were senior-level eng ineers or managers whose familiarity with a managerial writing style could be assumed and who submitted a sample popularized technical writing to demonstrate their versatility in communications.

It 1s by no means easy to produce a sample of good managerial technical writing. Several samples submitted in a managerial style were rejected as lacking clarity, polish or depth of technical understanding. The differences between good and medtocre managerial writing are often subtle. In the sections to follow I will try to make these differences as clear as I can.

\section{WHAT CONSTITUTES GOOD MANAGERIAL WRITING}

The plan for this section is to present examples of good managerial writing followed by a discussion of why the examples are of good quality. Knowing our firm's high standards of report writing, I have walked into the office next to mine and selected a bound volume at random as a source of examples. It happens to be a socioeconomic impact study for a new mining project. This will be a good source of examples because neither I nor you the reader are likely to know much about socio-economic impact assessment. All the examples to follow will be drawn from the same report, and names of compantes and locations will be changed to preserve confidentiality. Let's begin with the Table of Contents. It is lengthy, considering that the total report 18 only forty-two pages. Please read it through completely since we will be devoting a lot of attention to it in subsequent sections.
ABLE MINING LTD.

STAGE II SOCIO-ECONOMIC ASSESSMENT OF THE THERMCOAL PROJECT

\section{TABLE OF CONTENTS}

EXECUTIVE SUMMARY

Page No.

I. INTRODUCTION

A. THE SCOPE AND PURPOSE

B. THE APPROACH

II. THE PROJECT

A. THE PROJECT IS LOCATED NEAR CHIEF RIVER

B. MINING WILL BE BASED ON SURFACE MINING TECHNIQUES

C. CONSTRUCTION IS PLANNED TO COMMENCE IN 1983

D. CAPITAL COST IS ESTIMATED AT \$74 MILLION

E. ANNUAL OPERATING COSTS WILL EXCEED \$22 MILLION

III. EMPLOYMENT AND LABOUR FORCE

A. EXISTING SITUATION

B. EMPLOYMENT REQUI REMENTS

C. IMPACT OF PROJECT EMPLOYMENT

IV. POPULATION

A. HISTORIC LEVELS OF POPULATION GROWTH HAVE BEEN VERY HIGH

B. THERMCOAL PROJECT WILL HAVE A MINOR CONTRIBUTION TO FURTHER HIGH RATES OF POPULATION GROWTH

V. HOUSING DEVELOPMENT

A. THE REQUIRED 100 ADDITIONAL HOUSING UNITS CAN EASILY BE PROVIDED

B. CONSTRUCTION WORKERS WILL BE HOUSED IN THE COMMUNITY

VI. SERVICES

A. NO SERIOUS EDUCATIONAL PRESSURE WILL BE CREATED BY THE THERMCOAL PROJECT

B . RECREATIONAL FACILITIES CAN ALSO HANDLE MINEINDUCED POPULATION GROWTH

C. NO SIGNIFICANT EXPANSION OF CURRENT COMMERCIAL FACILITIES IS EXPECTED DUE TO THIS PROJECT

D. THE MINE'S IMPACT ON MEDICAL AND HEALTH FACILITIES IS EXPECTED TO BE INSIGNIFICANT

E. IMPACT ON OTHER FACILITIES AND SERVICES WILI ALSO BE MINIMAL

F. MANY LOCAL INDUSTRIAL SUPPORT ESTABLISHMENTS SHOULD BENEFIT FROM THE PROJECI 


\section{ABLE MINING LTD.}

STAGE II SOCIO-ECONOMIC ASSESSMENT OF THE THERMCOAL PROJECT

\section{TABLE OF CONTENTS}

VII. COMUNITY LAND USE AND PLANNING

Page No.

A. MINE-SITE DEVELOPMENT IS CONSISTENT WITH THE OFFICLAL REGIONAL PLAN

B. THE DISTRICT OF CHIEF RIVER CAN EASILY ACCOMMODATE POPULATION GROWTH

C. THE DOCK-SITE PIAN IS THE MOST SENSITIVE COMMUNITY PLANNING ISSUE

VIII. COMMUNITY INFRASTRUCTURE

A. THE SEWAGE SYSTEM COULD ACCOMMODATE A POPULATION OF 30,000

B. THE PROJECT WILL NOT CREATE STORM DRAINAGE PROBLEMS WITHIN CHIEF RIVER

C. THERE IS MORE THAN ADEQUATE HATER SUPPLY

D. HOUSING GROWTH WILL OCCUR IN SUBDIVISIONS MEETING CURRENT STANDARDS

IX. REGIONAL INFRASTRUCTURE

A. WITH THE EXCEPTION OF THE HAUL TO THE DOCK SITE, TRANSPORTATION EFFECTS ARE INSIGNIFICANT

B. THE MINE'S ELECTRIC POWER SUPPLY WILL COME FROM THE WESTERBROOK GENERATING STATION

X. ECONOMIC AND SOCIAL ADJUSTMENT CONSIDERATIONS

A. SIGNIFICANT MUNICIPAL FINANCIAL BENEFIT SHOULD RESULT FROM THE PROJECT

B. FEW SOCIAL ADJUSTMENTS WILL RESULT FROM THE MINE DEVELOPMENT

XI. SUMMARY OF EFFECTS AND KEY ACTIONS THAT ABLE MININC WILL UNDERTAKE TO INCREASE THE BENEFITS

A. FOUR MAJOR BENEFITS ARE EXPECTED FROM THE PROJECT

B. ABLE MINING IS COMMITTED TO A NUMBER OF KEY ACTIONS TO ENSURE MAXIMUM LOCAL BENEFIT

XII. CONCLUSION
Management writing of ten has a surprisingly large audience. Our example Table of Contents must be written to accommodate this potentially diverse readership. Please take a moment to glance through it again, this time pretending that you are any one of the following people:

- A Town Planner for the municipality of Chief River.

- The President of Able Mining.

- A store owner in Chief River.

- A member of the British Columbia Environment and Land Use Committee.

- A newspaper reporter with no time to spare, scanning for possible stories

- A harassed town council member trying to remember where you read that one item ....

- The Defence Counsel for Able Mining five years hence in an action initiated by the municipality of Chief River.

It is generally true that managenent writing finds a larger audience than the author expects. Reports are widely accessed, memos are passed upstalrs, letters are used as evidence in legal actions, and so on. In summary, we could say that management writing is understandable and useful to a potentially diverse readership.

\section{Ten Characteristics of Good Management Writing}

Now that we have seen the audience, we can look at the message and how it is presented. In each paragraph to follow, some aspect of management writing will be discussed and then summarized in a single 
underlined sentence for easy reference.

We can beg in with the needs of the people who will be reading the material. All of the hypothetical readers of our example Table of Contents share a common need. The need is for accurate information, presented in such a way that they can form a judgement, reach a decision or take some action. Management writing provides accurate Information as a basis for a judgement, a decision or an action.

How do all the potential readers differ? They each have their own vested interest. If the report were slanted toward one particular audience it would not be widely useful, and it would be less than completely accurate. The information is presented factually and objectively, leaving the judgements and decisions to the readers.

Some people are in a hurry and want a quick impression, while others want complete information that can be carefully studied. The presentation is complete, yet simple and concise.

A few of the readers are very sentor executives or government officials. Such people look skeptically at a writing style that lacks formality. The writing style is formal and dignified.

But many potential readers and sometimes even senior executives have difficulty with language that is too sophisticated or sentence structure that is too complex. Take, for example, line VI.B. from the Table of Contents. This could have read, "Recreational facilities have sufficient capacity to accommodate the population increase anticlpated from mining activity." Thankfully it instead simply says, "Recreational facilities can also handle mine-induced population growth." Though formal, the vocabulary and sentence structure are as simple as possible.

Each reader is a decision-maker who requires definite information. Most of the listings in the Table of Contents are in the form of definite and positive statements. In section V.A. for example, the authors are not talking about somewhere between 80 and 120 housing units depending on interest rates, vagaries of local versus imported labour, salary levels of employees, and so on. While such vagarles exist and might be discussed in the body of the report, the authors have taken their best estimate of 100 housing units and stated it decisively as a fact. This is very much in contrast with an academic style that is careful to qualify data sources, analytical techniques, theoretical presuppositions, and so on. An academic style is perceived by business people as waffling and lacking in decisiveness. A decision-maker needs to feel firm ground underfoot, whether it is there or not. The decisiveness required of people in management positions has led to a positive and confident style of writing at the management level. Information is expressed in a definite, positive and decisive way. This positive flavour in management communication is pervasive even when a negative situation is encountered. Many difficulties can arise in the business eovironment. Sales can be off, individuals or management teams can make mistakes and so on. When these negatives are discussed in any formal communication, whether written or verbal, there is still a positive and dignified flavour to the communication. An example is line vil.c. In the Table of Contents. One can imagine the extent of the conflict that is 
possible between Able Mining and local residents regarding a docksite plan. Rather than discussing the details of a conflict before it has been resolved, the authors have simply flagged it as," . . the most sensitive community planning issue." The presentation of negative information follows the unspoken rules of business etiquette.

One might notice the almost pedantic beginning of the report in II.A., where an entire section is devoted to the fact that the project is located near Chief River. This is followed by an equally pedantic section describing the project as a surface coal mine and so on. To anyone familiar with the project these sectlons represent information that is much too obvious to be included. The point is, however, that management reports are of ten read by a variety of people for a variety of purposes, and they are writen with this in mind. There is also a fringe benefit from this kind of ploddingly thorough report organization: busy managers can get a detafled sense of the entire report just by reading the Table of Contents. A good test of report organization is to see whether the headings can stand by themselves and tell a complete and coherent story. The presentation is organized into as many small steps as are needed for complete coverage of the information. Report organization is also used as a vehicle to achieve decisiveness in presenting information. At the lowest level of organization the detailed data may lack firmness. Estimates might really be in ranges rather than in single figures; there may be several "unknowns" in the situation. These things are discussed in the body of the report, but even when such ambiguities are presented they are still stated definitely. For example, "The required number of new singledwelling units 1s estimated at between 80 and 120 over a two year pertod." The lead paragraphs, conclusions, and headings for each section are then used to summarize the Information into decisive statements, eliminating any confusing details or ambiguities that have been presented in the body of the report. Moving from the lowest to the highest levels of report organization, statements and headings become progressively simpler and decisive. The final result is something like the set of firm statements given in our example Table of Contents. Report organization, lead statements, conclusions and section headings are used to give summary firmness to approximate or ambiguous data.

A management report has a special flavour that we can call communication from equal to equal; it is written so that both the author and the reader stand as equals. There is no hint of selling, hoping or pleading, which would make the author less credible than the reader. Similarly, there is no trace of directing, cajoling or teaching, which would suggest that the author is more qualified than the reader. The tone of a management report creates the feelIng that both author and reader are business professionals and that both are standing outside a situation that is being objectively described and evaluated. Management writing is communication between equals.

\section{SOURCES OF GOOD MANAGEMENT WRITING}

Surprisingly, it appears that there were enough examples in fust the Table of Contents of one report to allow us to look at most of the 
characteristics of good managerial technical writing. Additional examples of both good and poor managerial writing can be gained from businesses and governments in the following formats:

- Annual Reports

- Feasibility studies

- Impact studies

- Market studies

- Submissions to government regulatory agencies

- Briefs and applications

- Final reports on major projects

- Interim progress reports and documentation on major projects

- Project proposals.

Each of these has a characteristic style and format. Each, if good managerial writing, will exhibit the ten characteristics discussed above.

\section{CONCLUSION}

The ability to compete for a management-level technical writing position requires sound familiarity with technical and commercial reporting requirements as well as the ability to write in a cogent managerial style. This style has definite characteristics that set
It apart from other kinds of technical writing. The financial compensation for management-level technical writing positions can be substantial.

David Ayers is an Industrial psychologist with Currie, Coopers \& Lybrand, a major Canadian management consulting firm. He joined this firm after an eighteen year career in university teaching, counselling and administration. At present he is engaged in executive search, relocation counselling, psychological assessment, organizational development and counselling of senior executives with emotional or performance difficulties. 